\title{
Fairness and Ethics in Spending
}

\author{
Hassan B. Ghassan*
}

\author{
Department of Economics, Umm Al-Qura University, Saudi Arabia
}

\begin{abstract}
Islamic faith and the ethical dimensions of the individual and the community have a significant role in guiding economic behavior by connecting the worldly life to the hereafter. In the Islamic economics paradigm, by relating ethics to the economic behavior of spending, we exhibit the good (bad) attributes of ethical (unethical) behavior. In this paper, we contribute to developing a measure of the overspending and underspending that allows testing the presence of wastefulness and niggardliness.
\end{abstract}

Keywords: Consumer behavior, Spending, Ethical utility, Earning layer, Belief holding, Threshold spending, Islamic economics.

\section{INTRODUCTION}

Ethics have an excellent standing among all people. For both the ends and means, ethics emprise a number of good attributes such as: honesty, clemency, forbearance, kindness, bravery, chastity (continence), commitment, redemption, reliance, charity, generosity, patience, longanimity, leniency, mildness, intelligence, tranquility, quietness, serenity, loyalty, admonition, complacency, modesty, shyness, altruism, goodness, generosity, and so on. These qualities are supported and stimulated by the Islamic Shariah to expand the positive features of the human being. Simultaneously, the Shariah designs to abandon the malicious attributes such as: lying, cruelty, hatred, harshness, lewdness, corruption, cowardice, treason, perfidy, hypocrisy, theft, fraud, avarice, fury, wrath, folly, recklessness, stupidity, anxiety, lightness, cheating, greed, pride, dissoluteness, heartburning, evil, avarice, and so on. ${ }^{1}$ The good (malicious) attributes that inspire the human being are crucial for controlling his/her behaviors, so the human soul data determines them and instill inside each person's mortals.

The final divine law was the Islamic Shariah, which brings forth the human being from darkness to light and refines their instincts and psychological natures. These instincts grow inside their souls the good and innate values made by Almighty Allah, and fade the malicious instincts that test each human being. Accordingly, Allah said in the Quran within chapter (Surat) 70 Almiaraj

*Address correspondence to this author at the Department of Economics, Umm Al-Qura University, Saudi Arabia; Tel: +966 12 5298161; Fax: +966 12 5298163; E-mail: hbghassan@yahoo.com, hbghassan@uqu.edu.sa

${ }^{1}$ For more details on these attributes in Arabic language: http://www.al-islam.com/DetailedSearch.aspx?pageid=575\&Tab=1\&SubjectID= 19917
(Ways of ascent) in verses 19 to 25: "Man was created restless; touched by adversity, he is fretful; touched by good, he is ungenerous; except, the prayerful; those who are constant at their prayers; and those in whose wealth is a rightful share; for the beggar and the deprived." (Itani, Translation 2012). However, adherence to the Shariah will be weakened when the malicious and non-virtuous values grow, dominated and driven the human heart that influences all the human systems. In contrast, compliance to the Shariah will be strengthened when the good and virtuous values grow and purifies the human heart (Ghazali 1058-1111 AD i.e. 450-505 AH, Amin 1931, AlMaydani 1999, AlAdoui 1999).

Following on the dominance of the previous attributes and their repercussions, each act and opinion will be considered either fair or unfair for each attitude, and then the human being will submit to it or drop it. Therefore, the actions and statements of humankind represent and exhibit the resultants of what is in his/her own-soul from the laudable ethics he is endowed with and from which no laudable ethics he renounces. If there is reconciliation and pious processes in his heart and soul, then his conduct will be fair; and if there is depravation and irreverent processes in his heart and soul, then his doing will be depraved. It cannot be possible that human actions can be independent of what is within his soul, but his actions depend on and stem from it just like the branches of a tree and its fruits are attached to their origin even the roots lie in the soil.

Hasan (2005) pointed out in the Islamic economics literature that there is no correct estimation of the overspending threshold and the underspending threshold. In this paper, we develop an appropriate index-variable of the (un)ethical consumption, by using the average, the semi-standard deviation of the consumption, and the constant $\mathrm{k}$ from Chebyshev inequality.

(c) 2016 Lifescience Global 
Additionally, the mechanism of fair or moral behavior has been analyzed experimentally by Dal Bó and Dal Bó (2014). They show that the moral messages exert positive effects on the human behavior. Furthermore, they indicate that these impacts can be persistent in the presence of punishments and incentives system that affect the expectations and preferences of the humankind. Our present paper is theoretical, but we expect in a future paper to run an experimental design to capture the real behavior of Muslim versus non-Muslim when they are subjected to Islamic faith messages.

There is no economic theory free of ideological preconceptions. Popoveniuc (2014) qualifies the western economics to be autistic, and considers that economics neglects some of the essential explanatory variables of human behavior such as its ethical dimension. He points out the emergency to incorporate high ethical principles within economic rationality. This can makes economics more connected to concrete human lives. We expect that the belief holding or active faith would generate in the human being spirit more social perspective than the economic rationality which is intrinsically limited and bounded by logic rules (Gigerenzer 2010). However, the faith gives a large perspective and continuum rules, through Shariah norms, to make moral choice decisions in all domains without harming any members of the world-society. The moral choices are based on the faith holding, and such faith is constructed on the expected eternal utility. For example, such behavior leads to religious-motivated voluntary redistribution of income through Zakah and all social giving from wealthy group to poor group; as indicated by Elgin et al. (2013) this moral decision provides higher direct satisfaction.

The paper is organized as follows; Section 2 exhibits that faith is related to belief holding and ethical behavior appears through the humankind relationships and transactions. Section 3 addresses fairness in spending by identifying the overspending and underspending thresholds. We conclude in Section 4.

\section{ETHICS AND UTILITY RELATIONSHIP}

Good ethical values emerge from the bright attributes of the human psyche and are affected by the faith values that are strongly related to the double revelations i.e. Quran and Sunnah. Ethical values interact with faith values and evolve inside them through compliance with the Shariah instructions. These instructions lead to the straight path that makes the individual's behavior wise and successful in his/her worldly life and in the Hereafter. Meanwhile, if ethics are there without faith values, then ethics will be like a body without its spirit or like a tree without its roots. Therefore, Islamic values dynamically include faith as the basis of belief holding, and ethics as the basis of all humankind's relationships and transactions connected to society, economy or to policy. Prophet Mohammed, Peace Be Upon Him (PBUH), has been sent by Almighty Allah to complete honorable ethics, as though the ethics were incomplete before the Islamic legislation. For that, the real belief in the message of Mohammed PBUH leads up to more honorable and completed ethics. Some of the morality values prevailing in Western countries do not have a positive effect on their ethics dynamic. Such ethics are based on strict materialistic tasks and not associated with virtuous belief holding, but only appear as a reflection of worldly objectives without any faith dimensions or any religious commitments. If we assume that there is no ethics without religion and that there is no human beings without ethics, then at best the human being who solely follows Western culture, lives with only half of his/her social abilities.

For these reasons, the consumer behavior of the individual and the family is firstly related to the ethical values stemming from the faith values. This is because consumption, as an essential mechanism, helps the human being to perform what he/she is created for, which consists of complying to a religious worship system as determined by Almighty Allah. In the framework of this worship system, the individual has to achieve his/her economic objectives. Together faith and ethics reveal who obeys in Islamic economic behavior among the Muslim individuals (Almaydani, 1999). The Islamic faith values consist of the fundamental concepts and the Shariah statements that govern a Muslim's individual relationship with Almighty Allah and determine his belief holding. As for the ethical values, they correspond to the positive attributes that govern the individual relationship with the people through the fundamental principles and human law statements. These latter live up to the ethical values that could interact positively with the faith dimension to produce habits and natures that make the individual fair with his/her community and which inspire the community to be fair with its individuals.

Almighty Allah describes the moderate spending of mankind in the Holy Quran within chapter 25 AlFurqan (The criterion) in verse 67: "And those who, when they spend, are neither wasteful nor stingy, but choose a 
middle course between that.", as well as in chapter 17 Alisraa (The night journey) in verse 29: "And do not keep your hand tied to your neck, nor spread it out fully, lest you end up liable and regretful." From these two verses appear the importance of the subsistence economy (Bnu Kathir $1373 \mathrm{AD}$ ). It means that there is a level of fairness spending for the individual and the family that represents moderation between two vilified limits overspending and underspending. Such level of fairness in spending includes the idea of equilibrium in the individual and family spending behavior. The optimal consumption spending could rationally consist of maximizing the utility of the spending subjected to the earning constraint and the common welfare. Then, it is clear that the excessiveness or the niggardliness behavior in spending deviates from the equilibrium and the individual or family economy would be permanently perturbed.

The second verse compares the niggardliness as a human hand tied to its neck meaning the hand that almost does not spend anything. Also, it describes the spendthrift or the overspending as a fully spread human hand that almost cannot hold anything. The unfair behavior implies that the spendthrift will become sorrowful i.e. regretful due to his/her inability to spend again (Attabari 923 AD). His excessiveness culminates in a sudden stop of the spending. Also, the niggard denies welfare from himself and others. Such behavior leads him/her sooner or later to more anguish, disability and weakness as a result of his/her stinginess and miserliness.

Firstly, Halal utility is a legal Islamic principle, because it brings usefulness and averts damage and/or corruption either in the ethical sense or the material sense. According to the Shariah, such utility expresses a great achieved success (Falah) in the worldly life through materialistic and spiritual satisfaction. Also, there will be in the hereafter happiness via the reward by what no eye has seen, no ear has heard and what did not occur in the human mind. This utility has many faces; it includes material spending on the self (first self utility), spending for his family (his wife and children) and relatives -particularly his parents- (second self utility), and the spending for his community (social utility). This latter spending means that the wealthy consumer does not neglect the changes that happen in the utilities of the under-middle group and the mostly poor group. He/she would pursue the sacrifice of part or all of his/her permissible marginal utility so that the poor and needy group could satisfy their urgent necessities. It is probable that the marginal increase in the income of the wealthy group does not necessarily lead to his/her rushing the permissible utilities i.e. any desirable and embellished goods and services. The legitimate pursuit of a Muslim individual or an Islamic family is based on his/her righteous belief holding and not on his/her passion or unlawfully desires for the self. The task is also to amplify the Shariah permissible utilities and to reduce the wrong and prejudice in the Islamic society and across world societies. The Muslim individual pursuit of realizing his/her material satisfaction of reasonable wants cannot be disjointed from the faith and the ethical dimensions. Because when he/she satisfies his/her vital human body needs in terms of eating and drinking; and due to the conviction from his/her belief holding, he/she gets a self-recompense in the worldly life and retribution in the hereafter.

In this framework, he/she will consent and agree to his earning layer, because during the resurrection day there will be no questioning about his/her income level (considered predetermined in the Islamic paradigm). But he/she will be asked about how this income has been earned due to the importance of the Halal earning i.e. if his/her job is done in compliance to the Shariah. Also, he/she will be asked about how his/her income has been used due to the importance of the fairness in the living behavior. This test consists of whether his/her consumption is done fairly through the Halal utility, if the saving is run according to his/her family economic projects and if the Zakat and other social giving are operated as requested by the Shariah. As well as the Muslim consumer has to enjoy the smart, instinctive mind and the abundant natural goods that Almighty Allah makes available for all humankind from Adam (PBUH) to the last human being in the worldly life. Obviously the Muslim consumer has to avoid what Almighty prohibited for him as explained in the Quran and the Sunnah. It is noticeable that the number of the prohibitions is very few compared to the innumerable legislated things that make your life pleasant. This latter requires that the spending behavior should be in between underspending and overspending in the Shariah sense. The discipline in this averageness could be happening only, when the individual behaves as a consumer or saver or a Zakat giver by considering his/her Islamic faith holding and the worship system. The deviation from the previous averageness signifies a pursuit of waywardness and what the heart desires. Such deviation drives ultimately to severe economic harm and expands the sins that weaken the faith values of the individual and the entire society. 
The explanations of religious texts from the Quran and Sunnah, the rules of the Islamic law and the purposes or legal objectives of Shariah (Maqasid) are of the most significant incentives that make the Muslim consumer closer to the Islamic commitments. Through his/her observance of faith and ethical values when he/she behaves as a consumer and in particular during economic shocks and sudden changes, that happen in the economic and social conditions. These incentives are intended to illustrate the ruling of Almighty Allah in what the human being can do and decide in his/her behavior process, to clarify the Halal road, prohibited (Haram) ways (Ghazali 1058-1111 AD, AlEzz 1181$1262 A D$ ) and identify the Islamic paradigm. All this process leads to making rationale decisions or corrects the wrong decisions.

\section{FAIRNESS IN SPENDING}

From the Shariah rules of the Muslim behavior and on the base that all that is Halal is useful, and all Haram is harmful, the consumer spends only on what is Shariah permissible. The Muslim actions should be in conformity to what Almighty Allah instructs in the Quran and the Sunnah through His Messenger Muhammad (PBUH). The human beings expenses for goods and services are considered to be worship and obedience to Almighty Allah, implying then a reward system in the worldly life and the Hereafter. The Shariah rules consist of all things that are admissible, except things inconsistent with the text of the Quran and the Sunnah. Then, the human being has to prevent Haram spending to not lose his/her money because there is no Halal utility. Besides, Haram spending could cause an individual economic and social corruption and spread corruption into all layers of the society. The Shariah rule about spending on good things requires fairness and self-control away from any positive deviation (overspending or wastefulness) and any negative deviation (underspending or avarice). ${ }^{2}$ Here, the Shariah rules consist of all spending being licit except when it falls at the two tails of the spending.

Accordingly, the consumption system in the Islamic economics contains a large number of consumption spending models between two thresholds. These latter are a minimum of the spending that does not descend

\footnotetext{
${ }^{2}$ The wasteful is the worst form of overspending or excess spending; because the waster spends his money based on his/her passion by causing many sins. It also implies a loss of money that not brings a Shariah acceptable utility. The wasting is a form of an extravagant consumption that leads to economic harm by causing a probable decrease in the future earnings.
}

below the avarice threshold and a maximum of the spending that does not exceed the excessiveness threshold. This multiplicity of spending models will be reflected in the elasticities of the consumption spending by the disposable income or the budget spending. The diversity of spending will be detailed in another paper to address an Islamic consumer model. There is an interval of admissible consumption corresponding to many consumption behaviors according to the layers of earning as indicated by Shaibani in the book of AlKassb (The Earning Book) on page 9: "There are many layers of earning, the amount that must be available for each one i.e. the subsistence level of living allowing to perform the religious duties. It is supposed that this level is expressed in a real amount, and what is needed to do the religious duties becomes a duty, if the individual will not earn more of that a real amount he is in that capacity." 3

After the Halal spending avoiding all Shariah illicit goods and services, it is required from the righteous consumer to arrange his/her spending according to his/her priorities scale and respecting the rationale conditions. Such conditions include the earning constraint and the extent of his/her belief holding and the completed ethics. This rationale behavior supports achievement in the first order self-utilities for him/her self and his/her family and in second order the social utilities to reach a common welfare. The priorities in spending i.e. imperatives spending consist of getting the barest necessities or the living subsistence that covers eating, drinking, health, safety and housing, ${ }^{4}$ learning, and marriage in the first instance. As for the spending in needs i.e. recommended spending, to make life easier, which consists of rationally expanding the necessities without exceeding the threshold of the overspending. This rational expansion is implemented respecting his/her belief holding and ethical behavior. If it were otherwise, unconstrained spending on needs leads inevitably to the inflation process and then to borrowing that affects negatively the social, economic and health environments of the present and the future generations negatively. The spending in bettered needs i.e. permissible spending consists of expanding the quantity and the quality of needs to enjoy the good things of the worldly life without exceeding the threshold of overspending. This latter, during the

\footnotetext{
${ }^{3}$ http://www.islamicbook.ws/asol\%5Chanafi/alksb.pdf

${ }^{4}$ The housing need could be reached from an ownership or the leasehold. The house lease option is required because the individual cannot contract the loans through non-Islamic banks due to the prohibition of banking interest.
} 
spending time, depends on the current income of the wealthy group layer and the expected income when the spending priorities are planned. According to the cognitive model of Islamic economics, a positive relationship between income and consumption spending should not set free the increase in the consumption level. But, the individual or his/her family must control each marginal increase by checking if the new consumption level falls within an interval of ethical consumption, bounded by a threshold of underconsumption and a threshold of over-consumption.

The Sunnah of Prophet Mohammed (PBUH) has warned spending on desires and excessive pleasures which reflects vain-gloriousness and lordliness leads to loss in this worldly life and the hereafter. The Messenger of Almighty Allah said in a traceable Hadith, i.e. Saying of Prophet Mohammed (PBUH), narrated by Anas ibn Malik and legally effective by Alalbani in the Hadith $950^{5}$ "Who the worldly life is his/her main concern, Almighty makes his/her poverty in his/her heart and disperses his/her matter and he/she will receive in the worldly life only what it is scripted for $\mathrm{him} / \mathrm{her}$; and who the hereafter is his/her main concern, Almighty makes his/her richness in his/her heart and gathers his/her matter and he/she will get in an acquiescent worldly life." Considering Shaibani's model of consumption, earning for the imperative livelihood faced the spending on necessities (Shaibani, 750-805). Here also, fairness and ethical behavior are essentials for all groups in the society. Because it is probable that the consumption spending of the middle-income group might fall outside ethical consumption interval i.e. the individual or his/her family attains the unethical level of spending. Therefore, there is a great guidance in the Quran within chapter 65 Attalaq (The divorce) in verse 7: "The wealthy shall spend according to his means; and he whose resources are restricted shall spend according to what God has given him. God never burdens a soul beyond what He has given it. God will bring ease after hardship." Also, in chapter 42 Ashura (The consultation) in verse 27: "If God were to increase the provision to His servants, they would transgress on earth; but He sends down in precise measure whatever $\mathrm{He}$ wills. Surely, regarding His servants, $\mathrm{He}$ is Expert and Observant." This indicates that the enlarged individual livelihood does not occur at once, but it arises gradually to test the human being behavior. This gradual increase is a clemency to the mankind unto

\footnotetext{
${ }^{5}$ Series of legally effective Hadiths by Sheikh Alalbani, available in Arabic at:
} www.alalbany.net/4263 that he/she doesn't transgress with his/her money and not distracted by the desires. He/she has been created for worship Almighty the Only One and the Absolute Eternal. This economic explanation permits to clarify more the intertemporal model of the consumption theoretically. This model theorizes the dynamic consumption efforts in between the current and future time based on his/her earnings from the beginning of his/her economic time to the long-run future.

The wasteful avoidance helps either to expand the basis of Zakat and other donations, and/or to enlarge the level of saving. This level is related positively to the investment and also assists the individual and his/her family during the unexpected shocks in his/her earnings. It also expands the level of Zakat through economic growth and leads toward more social justice. Abstention from overspending, by preserving the feelings of the poor, needy, orphans, widows, sick and others, makes available a certain social resources composed of the Zakat, dole, testament, endowment and other goodness and ethical flows. It becomes clear from the divine guidance that the size of the spending is basically related to the spending budget. This budget depends on the available income for him/her self and his/her family spending after respecting all the social giving.

According to his/her Islamic faith holding and the worship system, the Muslim does not exceed what he/she can spend. But sometimes, the Muslim may be forced to borrow to achieve some of the imperative or needy spending purposes. For such reasons, it is required for each pietist and ethical person to equilibrate between his/her livelihood and his/her spending. The saving effort is required to avoid both the licit and the illicit borrowing when he/she needs the liquidity. Also, the legal necessity of the Zakat and the dole, to specific groups ${ }^{6}$ in the society, leads indeed to remedy the disparity between the incomes of different groups in the society. This transfer makes the poor and needy groups capable of spending on necessities. Such Zakat will bring to the individual and the family of these previous groups a decent livelihood in the Muslim society.

Hasan (2005) pointed out in the Islamic economics literature that there is no correct estimation of the overspending and the underspending thresholds

\footnotetext{
${ }^{6}$ The individual or family income of these groups does not reach the prescribed
} minimum amount liable to Zakah i.e. the threshold of income or assets. 
despite the effort of Ben Jilali and Azzamil (1992). ${ }^{7}$ The estimation of these thresholds is theoretically and empirically essential because it allows an in depth analysis of the Muslim consumer behavior. Much of the empirical research, which seeks to understand the ethical dimension in consumer behavior, is based on questionnaires and surveys of consumers (Fukukawa and Ennew 2010). By using specific instrumental variables, we suggest measures of the ethicalness of the consumer behavior; we find the appropriate indexvariable indicating (un)ethical consumption. Using the average and the semi-standard deviation of consumption, we define overconsumption in the second condition of (1a) and under-consumption in the second condition of $(1 b)$ :

$$
\begin{array}{r} 
\begin{cases}C_{\text {eth }, t} & \text { if } C_{t-1}-\left(\bar{C}_{+}+k \sigma_{+}\right)<0 \\
C_{n e t h+, t} & \text { if } C_{t-1}-\left(\bar{C}_{+}+k \sigma_{+}\right) \geq 0\end{cases} \\
\begin{cases}C_{e t h-, t} & \text { if } C_{t-1}-\left(\bar{C}_{-}+k \sigma_{-}\right)>0 \\
C_{n e t h-, t} & \text { if } C_{t-1}-\left(\bar{C}_{-}+k \sigma_{-}\right) \leq 0\end{cases}
\end{array}
$$

where $C_{e t h+, t}$ and $C_{\text {neth }, t}$ represent ethical consumption without waste or avarice and unethical consumption with waste or avarice in time $\mathrm{t}$, respectively. $\bar{C}_{+}\left(\bar{C}_{-}\right)$ stands for the average or the median of the observed consumption that exceeds (does not exceed) the trend or potential consumption. The $\sigma_{+}\left(\sigma_{-}\right)$is the semistandard deviation of the consumption when the observed consumption is greater (smaller) than its average, and $\sigma$ is the total standard deviation. The parameter $k$ is deduced from Chebyshev inequality (applicable to all distributions) and assumed greater than one. This parameter helps to estimate the threshold of the fairness interval of spending without wasteful and avarice behaviors. It considers that the probability of the absence of overconsumption and under-consumption is at least equal to the average of:

$$
\left(1-\frac{1}{k^{2}} \cdot \frac{\sigma_{+}^{2}}{\sigma^{2}}\right) \text { and }\left(1-\frac{1}{k^{2}} \cdot \frac{\sigma_{-}^{2}}{\sigma^{2}}\right)
$$

i.e. the ratio of the observed values that fall in the following interval:

$$
\left[\bar{C}_{-}-k \sigma_{-} ; \bar{C}_{+}+k \sigma_{+}\right]
$$

\footnotetext{
${ }^{7}$ They don't define any thresholds about the overspending or the underspending. They only suppose their existence and use the residuals of an equation of the consumption to identify, from the least square method, the positive residue as wasteful and the negative residue as avarice. The theoretical value is considered as the ethical consumption.
}

The first variable $C_{n e t h+t}$ in (1a) reflects that the Muslim consumer, who behaves ethically, does not overdo consumption spending, but measures and edifies it. Then, he/she doesn't behave close to either the wasteful or the avarice threshold. He/she edifies by adjusting and correcting the previous positive consumption deviations. For that, we assume that when the expected consumption (or lagged consumption) is lower than the average of the consumption plus an extent of positive deviations, consumption becomes with an ethical feature. While when the consumer behaves unethically, he/she overdoes in consumption spending and unleashes his/her desires, then he/she exceeds the thresholds of wastefulness and niggardliness. This tendency to the consumption solicitude occurs when the expected consumption exceeds the average of the consumption $\bar{C}$ plus an extent of positive deviations. Then, the consumption becomes unethical, because it exceeds its average as in the second definition of (1a).

Also, the first variable $C_{e t h+, t}$ in (1b) reflects that the Muslim consumer does not forget his share of the enjoyment and pleasure of the worldly life. So that he/she behaves in a way that is distant from niggardliness threshold. This latter consists of that the expected consumption would be equivalent to the mean of the consumption minus an extent of negative deviations. Also, the niggardliness will be intensified whenever the expected consumption is lower than the average of the consumption minus an extent of negative deviations as in the second definition of (1b).

Additionally, there is another way to determine the excess and shortage of consumption level empirically by capturing the long-run positive and negative error correction term through the threshold cointegration or more generally the asymmetric cointegration methodologies. The long and short memory of behavior consumption can be analyzed deeply through the Threshold Auto Regressive or Momentum Threshold Auto Regressive modeling combined with Component Generalized Auto-Regressive and Conditionally Heteroscedastic (TAR-CGARCH) structure of residuals in consumption function. This methodology allows to explain empirically the dynamic process of over and under consumption.

\section{CONCLUSION}

The Islamic values dynamically include faith as the basis of the belief holding, and ethics as the basis of all humankind relationships and transactions. Together 
faith and ethics reveal who adheres to Islamic economic behavior among the Muslim individuals. The Muslim individual pursuit of realizing his/her material satisfaction of reasonable wants cannot be disjointed from the faith and the ethical dimensions. The unfair behavior implies that the spendthrift will become sorrowful due to his/her inability to spend again and that his/her excessiveness will result in a sudden stop in the spending. There are three layers of spending: the imperative, recommended and permissible. The imperative spending consists of getting the barest necessities or the living subsistence; the recommended spending, to make life easier, consists of expanding rationally the necessities without exceeding the threshold of the overspending; and the permissible spending consists of expanding the quantity and the quality of needs to enjoy the good things of the worldly life without exceeding the threshold of the overspending. The Shariah rule maintains all spending is licit except when it falls at the two tails of the spending. The abstention from overspending, by preserving the feelings of the poor, needy, orphans, widows, sick and others, makes available certain social resources composed of the Zakat, dole, testament, endowment and other goodness and ethical outflows.

\section{REFERENCESIARABIC}

AlAdoui, Mustafa. 1999. Jurisprudence of Ethics and Transactions, Publisher Dar Al Majed Asiri, Jeddah, First edition.

AlEzz, bin Abd Salam. 1181-1262. The Benefits in Shortening Purposes. Publisher Dar contemporary thought, Damascus (1995). Reviewed by lyad Tabaa. http://ahlalhdeeth.com/vb/ attachment...3\&d=1202825338

AlMaydani, Abdul Rahman. 1999. Islamic Ethics and their Bases. Fourth edition, Publisher Dar Alqalam, Damascus. http://waqfeya.com/book.php?bid=884

Amin, Ahmed. 1931. A Book of Ethics. Third Edition, Egyptian National Library Press.

Attabari, Muhammad Jareer. 838-923. Collector of Statements on the Quran Interpretation. Volume 24, Publisher Dar Books world, Riyadh (2013). Reviewed by Abdullah Turki.
Ben Jilali, B. and Azzamil, Y. 1992. "Measuring the Consumption Function in an Islamic Framework." Journal of Islamic Economics Research 2(2):37-66.

Bnu Katyr Imad Eddine, Ismail 1301-1373. Interpretation of the Great Quran, 8 volumes. Publisher Dar Tieba (1999). Reviewed by Sami Salama. http://rowea.blogspot.com/2010/02/pdf-8.html

Ghazali, Abu Hamed. 1058-1111 AD. The Revival of the Religion Science. By I. Rifai and reviewed by AS. Shahin (1988), $1^{\text {st }}$ Ed.: Book of the Earnings and Livelihood, and Book Standards Behaviors of Living and Ethics of Prophethood. Publisher of Alahram Center for Translation and Publishing, Cairo. https://docs.google.com/file/d/0B8E9Z57shYOkYnITdV85eU 53TzQ/edit?pli=1

Shaibani, Muhammad ibn al-Hassan. 750-805 AD. Book of the Earning. Explained by Mohammed Sarkhasi. Verified by Abdul Fattah Abu Ghuda, first edition (1997), publisher Dar Albachaer Alislamia, Beirut and the Office of the Islamic publications, Aleppo. https://ia802604.us.archive.org/33/ items/al-Kasb-shebani/kasb.pdf www.islamicbook.ws/asol\%5Chanafi/alksb.pdf

\section{REFERENCES/ENGLISH}

Dal Bó, E. and Dal Bó, P. 2014. "Do the right thing: The effects of moral suasion on cooperation." Journal of Public Economics 117:28-38. http://dx.doi.org/10.1016/j.jpubeco.2014.05.002

Elgin, C., Goksel, T., Gurdal, MY. and Orman C. 2013 "Religion, income inequality, and the size of the government." Economic Modelling 30:225-234. http://dx.doi.org/10.1016/j.econmod.2012.08.017

Fukukawa, K. and Ennew, Ch. 2010. "What We Believe Is Not Always What We Do: An Empirical Investigation into Ethically Questionable Behavior in Consumption." Journal of Business Ethics 91:49-60. http://dx.doi.org/10.1007/s10551-010-0567-1

Gigerenzer, G. 2010. "Moral satisficing: Rethinking moral behaviour as bounded rationality." Topics in cognitive science 2(3):528554.

http://dx.doi.org/10.1111/j.1756-8765.2010.01094.x

Hasan, Z. 2005. "Treatment of Consumption in Islamic Economics: An Appraisal." JKAU: Islamic Economics 18(2):29-46. http://dx.doi.org/10.4197/islec.18-2.2

Itani, Talal 2012. This Quran could not have been produced by anyone other than God: The Quran. Published by ClearQuran, Dallas and Beirut. www.ClearQuran.com

Popoveniuc, B. 2014. "The Economy of Economics. For an Axiological Reflexive Reform." Procedia - Social and Behavioral Sciences 149:746 - 752. http://dx.doi.org/10.1016/j.sbspro.2014.08.303

Received on 06-11-2015

Accepted on 15-01-2016

Published on 18-08-2016

\section{DOI: http://dx.doi.org/10.6000/1929-7092.2016.05.24}

(c) 2016 Hassan B. Ghassan; Licensee Lifescience Global.

This is an open access article licensed under the terms of the Creative Commons Attribution Non-Commercial License (http://creativecommons.org/licenses/by-nc/3.0/) which permits unrestricted, non-commercial use, distribution and reproduction in any medium, provided the work is properly cited. 